\title{
Ileal amino acid digestibility in micronized full fat soybean meal and textured soy flour fed to piglets with or without multicarbohydrase and phytase supplementation
}

\author{
J.C. Dadalt ${ }^{\mathrm{a}}$, C. Gallardo ${ }^{\mathrm{a}}$, G.V. Polycarpo ${ }^{\mathrm{b}}$, D.A. Berto ${ }^{\mathrm{c}}$, M.A. Trindade Neto $^{\mathrm{a}, *}$ \\ a Department of Animal Science, University of São Paulo, Pirassununga, SP 13635-015, Brazil \\ b School of Technology and Agricultural Sciences, UNESP, Dracena, SP 17900-000, Brazil \\ c Department of Animal Science, UNESP, Botucatu, SP 18618-970, Brazil
}

\section{A R T I C L E I N F O}

\section{Keywords:}

Amino acid

Apparent digestibility

Standardized digestibility

Enzymes

Soybean products

\begin{abstract}
A B S T R A C T
Most amino acid (AA) digestibility values for feed ingredients are obtained using ileal-cannulated pigs. The ileal-cannulated pig model is not used with pigs younger than six weeks of age due to difficulties related to T-cannula implantation in the distal ileum and potential problems related to post-surgical recovery. Thus, the present experiment aimed to determine the digestibility of two ingredients in young pigs using the slaughter method. Fifty 23-d-old weaned pigs were divided into two experiments to evaluate the apparent total tract digestibility (ATTD) and apparent (AID) and standardized (SID) ileal amino acid digestibility in micronized full fat soybean meal (MFFS) and textured soy flour (TS) with or without phytase (Phy) and multi-carbohydrase (MC) supplementation. Each piglet was individually housed in a metabolic cage in a completely randomized experimental design with a $2 \times 2$ factorial arrangement of treatments to determine the effects of MC ( 0 and $0.2 \%$ ) and Phy ( 0 and $0.05 \%)$. During the first $8 \mathrm{~d}$, a diet was formulated to meet or exceed nutrient specifications for piglets. Subsequently, the animals were introduced to experimental diets for $10 \mathrm{~d}$ (a 6-d adaptation period followed by a 4-d faeces and urine total collection). A corn/dry-whey/milk-powder diet was used as a reference diet (RD). Ileal digesta was collected at slaughter ( $45 \mathrm{~d}$ of age) after a 4-d adaptation period with a low protein diet ( $5 \%$ casein). There was no effect of MC or Phy supplementation on nutrient and energy digestibility in MFFS. The SID of AA in MFFS without enzymes was on average $6 \%$ lower than in published data in the literature (NRC, 2012). Similarly, in TS, no interactions $(P>0.05)$ between enzymes were observed on AID or SID of essential AA. However, Phy supplementation improved the ATTD of crude protein (CP) and the SID of Arg, His, Glu and Pro $(P<0.05)$, while MC improved the SID $(P<0.01)$ of His, Cys, Glu, and Gly. It was difficult to compare these results with values from literature due to a lack of information regarding TS. As hypothesized, the results of experiments reported here suggest that the digestibility of nutrients and energy in MFFS is lower compared with literature values. However, since digestibility of raw materials differs from batch to batch and from experiment to experiment, more researches should be conducted to compare the digestibility of ingredients for piglets in different ages.
\end{abstract}

\footnotetext{
Abbreviations: AA, amino acid; ATTD, apparent total tract digestibility; AID, apparent ileal digestibility; SID, standardized ileal digestibility; BW, body weight; MC, multi-carbohydrase enzyme; Phy, phytase; MFFS, micronized full fat soybean meal; TS, textured soy flour; DM, dry matter; GE, gross energy; CF, crude fibre; CP, crude protein; ADF, acid detergent fibre; NDF, neutral detergent fibre; ME, metabolizable energy; RD, reference diet

* Corresponding author.

E-mail address: messiastn@usp.br (M.A. Trindade Neto).
} 


\section{Introduction}

Most AA digestibility values for feed ingredients are measured with pigs fitted with a T-cannula at the distal ileum. The pigs used in this type of study are usually not younger than six weeks to avoid potential age-related T-cannula implantation difficulties and post-surgical recovery. A detailed description of cannula preparation and pre- and post-operative care was previously given by Li et al. (1993). However, nutrient digestibility for weaned pigs might be overestimated because the feed formulation for weaned pigs is still based on digestibility data obtained from older animals with a more advanced physiological stage of gastrointestinal tract development. Age- and body weight-related differences in feed utilization and nutrient digestibility were reported previously (Trindade Neto et al., 2010). According to Marion et al. (2003), an acute phase of decreased digestive enzyme secretion occurs after weaning. When pigs are fed a solid diet, the physiological functions of the small intestine increase gradually (Marion et al., 2003; Boudry et al., 2004). The collection of samples in the distal ileum using the slaughter method could be an alternative to the T-cannula technique (Donkoh et al., 1994).

Soybean products are the primary protein source used to meet the AA requirements of pigs during different growing phases (Lawrence et al., 2003). However, consumption of soybean by nonruminant species can be limited by the presence of antinutritional factors, which can cause flatulency, diarrhoea, and reduced nutrient digestibility (Clarke and Wiseman, 2000). Heat processing procedures such as micronization have been reported to disrupt cell wall components and increase dry matter and nutrient digestibility in pigs (Lawrence, 1973) and poultry (Igbasan and Guenter, 1997). However, the use of micronized feedstuffs to reduce nutrient excretion and swine manure output has not been examined extensively and requires further evaluation (Zhang et al., 2003; Nyachoti et al., 2006). In textured soy flour, the moist extrusion used in the process may reduce the trypsin inhibitor concentration and antigenic properties of soybean, thereby increasing the nutrient availability in the lumen (Friesen et al., 1993). According to Rojas et al. (2016), the energy utilization may be improved by pelleting or extrusion processes, but the response seems to be greater for extrusion in diets that are relatively high in fibre. The cereal source and extrusion affect nutrient digestibility in pigs, and the effects of extrusion depend on the nature of the cereal (Rodrigues et al., 2016). According to Woyengo et al. (2016), the nutritive value of soybean in swine diets could be increased by the extrusion process.

The use of exogenous enzymes may reduce the adverse effects of antinutritional factors as demonstrated by an increase of nutrient use in poultry and swine diets (Kim et al., 2006; Li et al., 2010). Phytase increases the availability of P, which is the third most costly nutrient in pig diets (Woyengo et al., 2014). According to Woyengo and Nyachoti (2013), phytate reduces utilization of other dietary nutrients by binding to them or to digestive enzymes. However, there are conflicting and inconsistent results in the literature regarding the improvement of nutrient utilization from phytase supplementation in pig and poultry diets (Traylor et al., 2001; Adeola and Sands, 2003; Radcliffe et al., 2006; Centeno et al., 2007; Sands et al., 2009; Cowieson and Bedford, 2009; Kong and Adeola, 2011). Plant-based alternative feedstuffs also contain fibre, which limits nutrient use in pigs (Woyengo and Nyachoti, 2011). Therefore, adding supplemental carbohydrases to diets can increase the nutritive value of alternative feedstuffs (Zijlstra et al., 2010). According to Woyengo et al. (2014), carbohydrase supplementation may increase energy digestibility and AA availability. The objective of the current study was to determine the apparent total tract digestibility (ATTD) of nutrients and energy and the apparent (AID) and standardized (SID) ileal digestibility of AA in MFFS and TS with or without multicarbohydrase (MC) and phytase (Phy) supplementation in weaned pigs using the slaughter technique.

\section{Material and methods}

All research methods and procedures were approved by the ethics and animal experimentation committee at the University of Sao Paulo (project 2843/2012) and followed all the requirements in relation to animal welfare.

\subsection{Ingredients and enzymes}

The MFFS and TS samples used for the current study were obtained from Nutrialy and The Solae Company, respectively, both of which from Sao Paulo, Sao Paulo, Brazil. According to technical information from the companies, the MFFS was ultra-fine milled and heat treated with infrared radiation. Briefly, the infrared rays ( $\lambda$ from 1.8 to $3.4 \mu \mathrm{m}$ ) penetrate the grain, moving molecules that vibrate 60-150 thousand megacycles per second, heating the grain and vaporizing the water. The urease activity value of the MFFS, determined according to The American Oil Chemists' Society (AOCS, 1980), was $0.09 \Delta \mathrm{pH}$. The range considered optimal for heattreated soybeans is $<0.20 \Delta \mathrm{pH}$ (Butolo, 2002). The TS sample was obtained from soybeans milled to fine powder form and extruded at high temperature and moisture. The urease activity value of the TS was $0.06 \Delta \mathrm{pH}$.

The enzymes were a MC blend of $\alpha$-galactosidase, galactomannanase, $\beta$-xylanase and $\beta$-glucanase activities (ENDOPOWER BETA, Uniquimica, Sao Paulo, Brazil) and Phy (GENOPHOS, Uniquimica, Sao Paulo, Brazil). The MC consisted of 40\% dehydrated fermentation product from Aspergillus niger (PRL 2351) and Aspergillus oryzae (ATCC66222) by weight and 60\% dehydrated malted barley that provided per $\mathrm{kg}$ diet $700 ; 2200 ; 30,000$ and 22,000 units of $\alpha$-galactosidase, galactomannanase, xylanase and $\beta$ glucanase, respectively. The Phy was a Saccharomyces cerevisiae-derived (KCCM 80051), that contained genes of Escherichia coli and Citrobacter braakii and provided $500 \mathrm{FTU} / \mathrm{kg}$ diet. One unit of $\alpha$-galactosidase was defined as the quantity of the enzyme that liberates $1 \mu \mathrm{mol} p$-nitrophenol per min. One unit of galactomannanase was defined as the quantity of the enzyme that decreases to half the initial viscosity of galactomannan per min. One unit of xylanase was defined as the amount of the enzyme that generated $1 \mu$ mol of the xylose from xylan per minute at $\mathrm{pH} 5.5$ and $50{ }^{\circ} \mathrm{C}$ and one $\beta$-glucanase unit was defined as the amount of the enzyme that generated $1 \mu \mathrm{mol}$ of the reducing sugar glucose from $\beta$-glucan per minute at $\mathrm{pH} 4.8$ and $50{ }^{\circ} \mathrm{C}$. One Phy unit (FTU) was defined as the 
Table 1

Feed composition and nutrient content of reference diets for piglets $(\mathrm{g} / \mathrm{kg}$ diet $){ }^{\mathrm{a}}$

\begin{tabular}{|c|c|c|}
\hline Ingredients, $\%$ & Total collection diet ${ }^{2}$ & Ileal collection diet ${ }^{3}$ \\
\hline Corn & 613.5 & - \\
\hline Corn starch & 50.0 & 415.6 \\
\hline Test ingredient & - & - \\
\hline Soybean oil & 19.8 & 31.3 \\
\hline Dry whey & 150.0 & - \\
\hline Skim milk powder & 100.0 & - \\
\hline Dextrose & - & 210.0 \\
\hline Lactose & - & 200.0 \\
\hline Casein & - & 50.0 \\
\hline Choline & 0.1 & 0.1 \\
\hline Potassium chloride & - & 10.4 \\
\hline Sodium bicarbonate & 4.3 & 10.4 \\
\hline Dicalcium phosphate & 17.1 & 30.1 \\
\hline Limestone & 5.4 & 2.2 \\
\hline Cromium oxide & 3.0 & 3.0 \\
\hline Zinc oxide & 3.5 & 3.5 \\
\hline Vitamin Premix & 1.0 & 1.0 \\
\hline Mineral premix & 1.0 & 1.0 \\
\hline Cellulose & 30.0 & 30.0 \\
\hline Antioxidant & 0.1 & 1.2 \\
\hline Flavoring & 1.2 & 0.2 \\
\hline Total & 1000 & 1000 \\
\hline \multicolumn{3}{|l|}{ Calculated composition, \% } \\
\hline Dry matter & 904.1 & 938.4 \\
\hline Metabolizable energy $(\mathrm{mJ} / \mathrm{kg})$ & 14.19 & 13.94 \\
\hline Crude protein & 90.1 & 42.6 \\
\hline Calcium & 8.5 & 8.5 \\
\hline Digestible P & 4.5 & 4.5 \\
\hline Sodium & 2.8 & 2.8 \\
\hline Chlorine & 3.1 & 4.9 \\
\hline Potassium & 6.1 & 5.2 \\
\hline Linoleic acid & 22.1 & 16.5 \\
\hline
\end{tabular}

${ }^{2,3}$ Corn/dry-whey/milk-powder and starch reference diets, respectively. Test ingredient replaced $30 \%$ of reference diet, with or without multicarbohydrase $(200 \mathrm{~g} / \mathrm{t})$; phytase $(50 \mathrm{~g} / \mathrm{ton})$ and multicarbohydrase $(200 \mathrm{~g} / \mathrm{t})+$ phytase $(50 \mathrm{~g} / \mathrm{t})$, respectively.

a As fed basis.

* Premix that provided per kilogram of piglet diet: vitamin A $10000 \mathrm{IU}$, vitamin D $1650 \mathrm{IU}$, vitamin E $60 \mathrm{IU}$, vitamin K $2 \mathrm{mg}$, Thiamine $1.2 \mathrm{mg}$, Riboflavin $4 \mathrm{mg}$, Pyridoxine 0.22, vitamin B12 $22 \mu \mathrm{g}$, Pantothenic acid $17 \mathrm{mg}$, Folic acid $0.40 \mathrm{mg}$, Niacin $30 \mathrm{mg}$, Biotin $0.15 \mathrm{mg}$, Se $0.36 \mathrm{mg}$, I $1.1 \mathrm{mg}$, Fe $90 \mathrm{mg}$, Cu $10.5 \mathrm{mg}$, Zn $118 \mathrm{mg}$, Mn $40 \mathrm{mg}$.

quantity of enzyme required to liberate $1 \mathrm{mmol}$ inorganic phosphate per minute, at pH-range $1.5-6.5$, from an excess of $15 \mathrm{mM}$ sodium phytate at $37^{\circ} \mathrm{C}$. The maximum activity was defined at $\mathrm{pH} 4.5$.

\subsection{Diets and experimental design}

Fifty 23-d-old weaned pigs were divided into 2 experiments with twenty-five animals in each group and housed individually in metabolism crates with transparent sides and woven flooring. In both experiments, MFFS-Experiment 1 and TS-Experiment 2, 5 corn/dry-whey/milk-powder-based diets were used to determine the ATTD of energy and nutrients; subsequently, 5 corn starchbased diets containing 5\% casein were provided to quantify the AID and SID of AA (Table 1), totalling 4 experimental dietary treatments and one reference dietary treatment ( 5 pigs per treatment) in each evaluation period. The reference diet was used only to be able to account for the digestibility of the nutrients and energy in the test ingredients. In the calculation of digestibility coefficients, a $2 \times 2$ factorial design with 2 levels of Phy (0 and $0.2 \%)$ and 2 levels of MC (0 and $0.05 \%)$ was used. For the four experimental treatments, $30 \%$ of the reference diet was replaced with a test ingredient (MFFS or TS) without enzyme (70\% control diet $+30 \%$ test ingredient), with multicarbohydrase (70\% control diet $+30 \%$ test ingredient $+0.05 \% \mathrm{MC})$, with phytase (70\% control diet $+30 \%$ test ingredient $+0.2 \%$ Phy) or with a combination of both enzymes (70\% control diet $+30 \%$ test ingredient $+0.05 \% \mathrm{MC}+0.2 \%$ Phy). Ferric oxide and chromic oxide $(0.3 \%)$ were used as indigestible markers in the total and ileal collection diets, respectively.

\subsection{Feeding and sample collection}

During the first $8 \mathrm{~d}$ (after weaning) a diet was formulated to meet or exceed (NRC, 2012) nutrient specifications for piglets. Subsequently, the animals were introduced to the experimental diets for $10 \mathrm{~d}$ (a 6-d adaptation period followed by a 4-d faeces and urine total collection). Ferric oxide $(0.3 \%)$ was added to the morning meal on $\mathrm{d} 7$ and 10 to mark the beginning and the conclusion of 
faecal collection. In the initial adaptation period, the body weight averages were $8.5 \pm 0.5 \mathrm{~kg}$ and $9.2 \mathrm{~kg} \pm 0.9 \mathrm{~kg}$ for Experiments 1 and 2, respectively. The daily amount of feed was provided in 2 equal meals at 0800 and $1700 \mathrm{~h}$. Pigs were allowed ad libitum access to water throughout the experiment. Faecal samples were collected twice daily at 0730 and $1730 \mathrm{~h}$ and stored at $-20{ }^{\circ} \mathrm{C}$ immediately after collection. The urine was routed through the drainage point in a urine collection tray placed underneath the metabolism crates into containers via a funnel. Urine was collected in tared bottles with $15 \mathrm{~mL}$ of $18 \mathrm{M}$ sulfuric acid to lower the pH of the urine to less than 3. For each successive 24-h collection period, a $5 \%$ aliquot was taken. Aliquots were pooled for each pig in the $\mathrm{N}$ balance period and stored at $4{ }^{\circ} \mathrm{C}$. At the completion of the $\mathrm{N}$ balance period, the pooled samples were subsampled for further analyses.

After the total collection, the corn-starch based diet and the four other experimental diets were provided to the fifty piglets for $4 \mathrm{~d}$, followed by slaughter at $45 \mathrm{~d}$ of age. Digesta samples were collected from the terminal ileum (approximately $30 \mathrm{~cm}$ segment). Before slaughter, the pigs were weighed and then given an intramuscular injection of acepromazine maleate $(0.3 \mathrm{mg} / \mathrm{kg}$ of BW) mixed in a single syringe with $15 \mathrm{mg}$ of ketamine hydrochloride/kg BW as a pre-anaesthetic tranquilizer. Once tranquilized sufficiently, approximately $20 \mathrm{mg}$ of thiopental/kg BW was administered by intracardiac injection.

\subsection{Sample analyses and data processing}

Diet, MFFS, TS and faecal samples were dried in a forced air oven at $55^{\circ} \mathrm{C}$ for $48 \mathrm{~h}$, weighed, finely ground through a 2 -mm screen, and analysed using AOAC (2005) procedures for dry matter (930.15), fat (2003.06) and ash (942.05). The ADF content and NDF content in the diets were determined according to the method of Goering and Van Soest (1970), whereas gross energy (GE) content was measured with an adiabatic bomb calorimeter (IKA ${ }^{\circ}$ C5000, Germany) using benzoic acid as the calibration standard. Crude protein content was determined using Kjeldahl procedures (analyser model Tecnal TE/036/1; Tecnal Equipamentos para Laboratório Ltda, Piracicaba, Brazil). Urine samples were freeze-dried and analysed for GE. Ileal digesta samples were freeze-dried, ground and analysed for DM, AA and $\mathrm{Cr}_{2} \mathrm{O}_{3}$. Chromic oxide in the diets and ileal digesta were analysed by atomic absorption spectrophotometry according to Williams et al. (1962). Amino acid content was determined according to AOAC (2005) procedure 994.12 (alternative 3). Briefly, a 100-mg sample was hydrolysed with $6 \mathrm{M} \mathrm{HCl}$ at $110^{\circ} \mathrm{C}$ for $24 \mathrm{~h}$ followed by neutralization with $4 \mathrm{~mL}$ of $25 \%$ (wt/vol) $\mathrm{NaOH}$ and was cooled to room temperature. The mixture was then equalized to a 50 -mL volume with sodium citrate buffer ( $\mathrm{pH}$ 2.2) and analysed using an AA analyser (1260 Infinity LCs, Agilent Technologies, Santa Clara, California, USA). Methionine and cysteine were oxidized with performic acid prior to hydrolysis. Tryptophan was not determined. All analyses were completed in duplicate.

\subsection{Calculation and statistical analyses}

The apparent total tract digestibility (ATTD) of nutrients was determined by the total collection method as described by Woyengo et al. (2010) using the following equation:

$$
\operatorname{ATTD}(\%)=100 *\left(\mathrm{NI}-\mathrm{NO}_{\text {faeces }}\right) / \mathrm{NI} \text {, }
$$

where $\mathrm{NI}$ is the nutrient or energy intake $\left(\mathrm{g}\right.$ or $\mathrm{mJ} / \mathrm{kg}$ ) and $\mathrm{NO}_{\text {faeces }}$ is the nutrient or energy output in faeces $(\mathrm{g}$ or $\mathrm{mJ} / \mathrm{kg}$ ).

The digestible energy (DE) and metabolizable energy (ME) values of the test ingredients (TI) were determined using the following equations:

$\mathrm{DE}(\mathrm{mJ} / \mathrm{kg})=[($ total tract GE digestibility for TI, \%) * (GE value of TI, $\mathrm{mJ} / \mathrm{kg}) / 100]$

and

$\mathrm{ME}(\mathrm{mJ} / \mathrm{kg})=[(\mathrm{GE}$ retention for TI, \%) $\times(\mathrm{GE}$ value for TI, $\mathrm{mJ} / \mathrm{kg}) / 100]$

The gross energy retention was calculated using the following equation:

GE retention $(\%)=100 *\left[\left(\mathrm{GE} \mathrm{I}-\mathrm{GE} \mathrm{O} \mathrm{O}_{\text {faeces }}-\mathrm{GE} \mathrm{O}_{\text {urine }}\right) / \mathrm{GE} \mathrm{I}\right]$,

where GE I is the GE intake ( $\mathrm{mJ} / \mathrm{kg}$ ), GE $\mathrm{O}_{\text {faeces }}$ is the energy output in faeces $\left(\mathrm{mJ} / \mathrm{kg}\right.$ ), and GE $\mathrm{O}_{\text {urine }}$ is the energy output in urine $(\mathrm{mJ} / \mathrm{kg})$.

Apparent ileal AA digestibility was calculated using the following formula (Nyachoti et al., 1997):

$$
\text { AID }(\%)=100-\left[100 *\left(\mathrm{AA}_{\text {digesta }} * \mathrm{Cr}_{2} \mathrm{O}_{3 \text { diet }}\right) /\left(\mathrm{AA}_{\text {diet }} * \mathrm{Cr}_{2} \mathrm{O}_{3 \text { digesta }}\right)\right.
$$

where $\mathrm{AA}_{\text {diet }}$ and $\mathrm{AA}_{\text {digesta }}$ are the concentrations $(\mathrm{mg} / \mathrm{kg} \mathrm{DM})$ of $\mathrm{AA}$ in the diet and digesta, respectively, and $\mathrm{Cr}_{2} \mathrm{O}_{3 \mathrm{diet}}$ and $\mathrm{Cr}_{2} \mathrm{O}_{3 \text { digesta }}$ are the concentrations $(\mathrm{mg} / \mathrm{kg} \mathrm{DM})$ of the indigestible marker in the diet and digesta, respectively. Apparent ileal AA digestibility was standardized using average values for basal endogenous AA losses calculated using the following formula (Nyachoti et al., 1997):

$$
\mathrm{AA}_{\mathrm{EL}}(\mathrm{g} / \mathrm{kg})=\mathrm{AA}_{\text {digesta }} *\left(\mathrm{Cr}_{2} \mathrm{O}_{3 \text { diet }} / \mathrm{Cr}_{2} \mathrm{O}_{3 \text { digesta }}\right)
$$

where $\mathrm{AA}_{\mathrm{EL}}=$ average endogenous $\mathrm{AA}$ loss in casein diet $(\mathrm{g} / \mathrm{kg}$ of $\mathrm{DM})$.

The determined endogenous ileal AA losses (g/kg of DMI) were as follow: Arg, 0.50; His, 0.31; Ile, 0.50; Leu, 0.80; Lys, 0.41; Met, 0.21; Phe, 0.52; Thr, 0.93; Val, 0.67; Ala, 0.76; Asp, 0.60; Glu, 1.13; Pro, 0.95; Ser, 0.99, and Tyr, 0.35 g/kg. 
Table 2

Analyzed amino acids content of micronized full fat soybean (MFFS) and textured soy flour (TS) used for the apparent and standardized ileal digestibility determination $(\mathrm{g} / \mathrm{kg}$, as-fed basis). ${ }^{\text {a }}$

\begin{tabular}{lll}
\hline Item, \% & Ingredient & \\
\cline { 2 - 3 } & MFFS & TS \\
\hline Dry matter & 950.1 & 959.3 \\
Indispensable AA & & \\
Arginine & 30.3 & 40.3 \\
Histidine & 10.8 & 14.5 \\
Isoleucine & 20.2 & 25.2 \\
Leucine & 30.9 & 40.9 \\
Lysine & 25.9 & 34.4 \\
Methionine & 4.4 & 5.2 \\
Phenylalanine & 20.4 & 26.6 \\
Threonine & 18.2 & 23.6 \\
Valine & 23.0 & 28.7 \\
Dispensable AA & & \\
Alanine & 17.4 & 22.8 \\
Aspartic acid & 55.1 & 72.8 \\
Cysteine & 04.1 & 4.2 \\
Glutamic acid & 69.1 & 82.5 \\
Glycine & 16.7 & 22.3 \\
Proline & 19.2 & 26.2 \\
Serine & 21.5 & 28.8 \\
Tyrosine & 15.3 & 20.0 \\
Total AA & 402.7 & 526.0 \\
\hline & & \\
\hline
\end{tabular}

${ }^{\text {a }}$ R: Reference diet; MC: multicarbohydrase; Phy: Phytase.

Standardized ileal digestibility (SID) was calculated according to the equation below as described by Opapeju et al. (2006):

$$
\operatorname{SID}(\%)=\left[\mathrm{AID}+\left(\mathrm{AA}_{\mathrm{EL}} / \mathrm{AA}_{\text {diet }}\right)\right] * 100
$$

The data were analysed by a two-way ANOVA using the GLM procedure of SAS (SAS Inst. Inc., Cary, NC). Significant main effects were declared when $P<0.05$. The homogeneity of variances was evaluated by Hartley test and the normality of residuals by the Shapiro-Wilk test (UNIVARIATE procedure). The statistical model used was

$$
Y_{i j}=\mu+a_{i}+b_{j}+\left(a_{i} \times b_{j}\right)+e_{i j}
$$

where Yij = variable response of piglets fed multicarbohydrase (i) and phytase (j); $\mu=$ overall effect of average; ai $=$ fixed effect for multicarbohydrase; $\mathrm{bj}=$ fixed effect for phytase; $(\mathrm{ai} \times \mathrm{bj})=$ interaction between multicarbohydrase and phytase; and eij $=$ error term (residue).

\section{Results}

\subsection{Experiment 1: micronized full fat soybean meal}

The analysed composition of MFFS was DM, $950.1 \mathrm{~g} / \mathrm{kg} \mathrm{GE}, 21.8 \mathrm{~mJ} / \mathrm{kg}$; CP, $382 \mathrm{~g} / \mathrm{kg}$; ash, $56 \mathrm{~g} / \mathrm{kg}$; CF, $19 \mathrm{~g} / \mathrm{kg}$; ADF, $38 \mathrm{~g} / \mathrm{kg}$; and fat, $240 \mathrm{~g} / \mathrm{kg}$ (Table not shown). The amino acid profile and ATTD of MFFS are shown in Tables 2 and 3, respectively. The amino acid concentration in the experimental diets with $300 \mathrm{~g} / \mathrm{kg}$ MFFS replacing the reference diet was uniform and homogeneous, as expected (Table not shown). There were no isolated effects or interaction effects of MC and Phy on nutrient digestibility, and the results are presented in Tables 4 and 5.

\subsection{Experiment 2: textured soy flour}

The analysed composition of TS was DM, 959 g/kg; GE, $17.3 \mathrm{~mJ} / \mathrm{kg}$; CP, $518 \mathrm{~g} / \mathrm{kg}$; ash, $66 \mathrm{~g} / \mathrm{kg}$; CF, 16 g/kg; NDF, $60 \mathrm{~g} / \mathrm{kg}$; and ADF, $51 \mathrm{~g} / \mathrm{kg}$ (Table not shown). As occurred in Experiment 1, the AA concentrations in the treatment diets with $30 \%$ TS were also homogeneous. As presented in Tables $6-8$, Phy improved the ATTD of CP $(P<0.01)$ and the AID and SID of Arg, His, Glu and Pro $(P<0.05)$. The MC also improved the ATTD of CP $(P<0.05)$ and the SID of His, Cys, Glu and Gly $(P<0.01)$. There were no interactions $(P>0.05)$ between enzymes on the AID or SID of essential AA. Interactions $(P<0.05)$ from MC and Phy were found only on the AID and SID of Ser and Tyr. The AID and SID of most AA in TS, with or without enzymes was higher than $90 \%$. 
Table 3

Coefficient of apparent total tract digestibility of energy and nutrients in micronized full fat soybean (MFFS) with or without enzymes for weaned piglets. ${ }^{\text {a }}$

\begin{tabular}{|c|c|c|c|c|c|c|c|c|}
\hline \multirow[t]{2}{*}{ Item, \% } & \multicolumn{4}{|c|}{ Treatment } & \multirow[t]{2}{*}{ SEM } & \multicolumn{3}{|c|}{$P$-value ${ }^{\mathrm{b}}$} \\
\hline & MFFS & $\begin{array}{l}\text { MFFS + } \\
\text { MC }\end{array}$ & $\begin{array}{l}\text { MFFS + } \\
\text { Phy }\end{array}$ & $\begin{array}{l}\text { MFFS + } \\
\text { MC + Phy }\end{array}$ & & MC & Phy & MC*Phy \\
\hline DM & 0.860 & 0.852 & 0.860 & 0.873 & 0.046 & 0.794 & 0.278 & 0.304 \\
\hline $\mathrm{CP}$ & 0.842 & 0.850 & 0.851 & 0.862 & 0.039 & 0.224 & 0.202 & 0.834 \\
\hline $\mathrm{N}$ retention & 0.630 & 0.667 & 0.649 & 0.664 & 0.088 & 0.162 & 0.675 & 0.532 \\
\hline Ash & 0.565 & 0.521 & 0.574 & 0.598 & 0.173 & 0.768 & 0.234 & 0.344 \\
\hline $\mathrm{DE}(\mathrm{mJ} / \mathrm{kg})^{*}$ & 19.38 & 19.45 & 19.48 & 19.71 & 0.009 & 0.409 & 0.333 & 0.660 \\
\hline $\mathrm{ME}(\mathrm{mJ} / \mathrm{kg})^{\prime \prime}$ & 18.70 & 18.62 & 18.58 & 18.97 & 0.011 & 0.489 & 0.606 & 0.294 \\
\hline $\mathrm{ME} / \mathrm{GE}$ & 0.776 & 0.773 & 0.771 & 0.778 & 0.041 & 0.850 & 0.991 & 0.578 \\
\hline
\end{tabular}

a MC: multicarbohydrase; Phy: phytase. DM: Dry matter; CP: Crude protein; DE: Digestible energy; ME: Metabolizable energy; ME/GE: Metabolizable energy/Gross energy. SEM: Standard error of mean.

$\mathrm{b}$ Effect of MC, Phy and interaction MC*Phy, respectively.

* DM-basis.

\section{Discussion}

\subsection{Experiment 1: micronized full fat soybean meal}

The latest edition of Nutrient requirements for swine (NRC, 2012) does not provide information specifically about MFFs; however, a similar product, full fat soybean (FFS), has been described and its values for GE, CP, fat and ash are in agreement with the values of MFFS determined in this study: $22.5 \mathrm{~mJ} / \mathrm{kg} ; 386,208$ and $50 \mathrm{~g} / \mathrm{kg}$, respectively. The values presented in the nutrient requirements for swine (NRC, 2012) for CF (42 g/kg) and ADF (64 g/kg) are higher, whereas NDF (103 g/kg) is lower than those in the present experiment. The composition and nutritive value of MFFS presented in the food composition and nutritional requirements by Rostagno et al. (2011) are as follows: $22.7 \mathrm{~mJ} / \mathrm{kg}$; 402, 221, 46, 14, 60 and $283 \mathrm{~g} / \mathrm{kg}$ for GE; CP; fat; ash; CF; ADF and NDF, respectively.

In the current study, despite a CP concentration for MFFS similar to that reported by NRC (2012) for FFS, the AA profile was different, probably due to differences between soybean cultivars. These differences in ingredient composition could alter the

Table 4

Coefficient of apparent ileal digestibility of amino acids in micronized full fat soybean (MFFS) with or without enzymes for weaned piglets. ${ }^{\text {a }}$

\begin{tabular}{|c|c|c|c|c|c|c|c|c|}
\hline \multirow[t]{2}{*}{ Item, $\%$} & \multicolumn{4}{|c|}{ Treatment } & \multirow[t]{2}{*}{ SEM } & \multicolumn{3}{|c|}{$P$-value $e^{\mathrm{b}}$} \\
\hline & MFFS & $\begin{array}{l}\text { MFFS + } \\
\text { MC }\end{array}$ & $\begin{array}{l}\text { MFFS + } \\
\text { Phy }\end{array}$ & $\begin{array}{l}\text { MFFS + } \\
\text { MC + Phy }\end{array}$ & & MC & Phy & MC*Phy \\
\hline \multicolumn{9}{|c|}{ Indispensable AA } \\
\hline Arginine & 0.716 & 0.742 & 0.746 & 0.727 & 0.128 & 0.894 & 0.784 & 0.437 \\
\hline Histidine & 0.698 & 0.723 & 0.718 & 0.696 & 0.140 & 0.979 & 0.910 & 0.445 \\
\hline Isoleucine & 0.599 & 0.665 & 0.643 & 0.644 & 0.134 & 0.226 & 0.675 & 0.243 \\
\hline Leucine & 0.681 & 0.704 & 0.691 & 0.678 & 0.123 & 0.851 & 0.765 & 0.495 \\
\hline Lysine & 0.758 & 0.753 & 0.728 & 0.721 & 0.095 & 0.735 & 0.118 & 0.954 \\
\hline Methionine & 0.723 & 0.721 & 0.704 & 0.697 & 0.141 & 0.879 & 0.497 & 0.925 \\
\hline Phenylalanine & 0.688 & 0.725 & 0.714 & 0.690 & 0.130 & 0.805 & 0.885 & 0.275 \\
\hline Threonine & 0.614 & 0.614 & 0.630 & 0.616 & 0.082 & 0.684 & 0.614 & 0.722 \\
\hline Valine & 0.652 & 0.669 & 0.664 & 0.658 & 0.150 & 0.881 & 0.989 & 0.719 \\
\hline Means & 0.681 & 0.702 & 0.693 & 0.681 & - & - & - & - \\
\hline $\mathrm{SD}^{\mathrm{c}}$ & 5.15 & 4.44 & 3.95 & 3.60 & - & - & - & - \\
\hline \multicolumn{9}{|l|}{ Dispensable AA } \\
\hline Alanine & 0.667 & 0.679 & 0.688 & 0.693 & 0.060 & 0.459 & 0.165 & 0.768 \\
\hline Aspartic acid & 0.669 & 0.683 & 0.660 & 0.690 & 0.079 & 0.189 & 0.966 & 0.601 \\
\hline Cysteine & 0.642 & 0.654 & 0.641 & 0.663 & 0.091 & 0.335 & 0.180 & 0.564 \\
\hline Glutamic acid & 0.711 & 0.733 & 0.740 & 0.733 & 0.161 & 0.824 & 0.677 & 0.686 \\
\hline Glycine & 0.666 & 0.669 & 0.658 & 0.671 & 0.083 & 0.375 & 0.223 & 0.445 \\
\hline Proline & 0.701 & 0.713 & 0.704 & 0.699 & 0.111 & 0.882 & 0.814 & 0.721 \\
\hline Serine & 0.700 & 0.727 & 0.715 & 0.715 & 0.061 & 0.295 & 0.900 & 0.292 \\
\hline Tyrosine & 0.689 & 0.724 & 0.675 & 0.695 & 0.153 & 0.405 & 0.525 & 0.818 \\
\hline Means & 0.680 & 0.698 & 0.685 & 0.695 & - & - & - & - \\
\hline $\mathrm{SD}^{\mathrm{c}}$ & 2.32 & 3.00 & 3.30 & 2.23 & - & - & - & - \\
\hline
\end{tabular}

${ }^{\text {a }}$ MC: multicarbohydrase; Phy: Phytase. SEM: Standard error of mean.

${ }^{\mathrm{b}}$ Effect of MC, Phy and interaction MC*Phy, respectively.

c Standard deviation. 
Table 5

Coefficient of standardized ileal digestibility of amino acids in micronized full fat soybean meal (MFFS) with or without enzymes for weaned piglets. ${ }^{\text {a }}$

\begin{tabular}{|c|c|c|c|c|c|c|c|c|}
\hline \multirow[t]{2}{*}{ Item, \% } & \multicolumn{4}{|c|}{ Treatment } & \multirow[t]{2}{*}{ SEM } & \multicolumn{3}{|c|}{$P$-value ${ }^{\mathrm{b}}$} \\
\hline & MFFS & $\begin{array}{l}\text { MFFS + } \\
\text { MC }\end{array}$ & $\begin{array}{l}\text { MFFS + } \\
\text { Phy }\end{array}$ & $\begin{array}{l}\text { MFFS + } \\
\text { MC + Phy }\end{array}$ & & MC & Phy & MC*Phy \\
\hline \multicolumn{9}{|c|}{ Indispensable AA } \\
\hline Arginine & 0.765 & 0.790 & 0.795 & 0.775 & 0.128 & 0.917 & 0.794 & 0.423 \\
\hline Histidine & 0.770 & 0.794 & 0.790 & 0.766 & 0.140 & 0.991 & 0.898 & 0.425 \\
\hline Isoleucine & 0.660 & 0.727 & 0.706 & 0.705 & 0.134 & 0.234 & 0.659 & 0.213 \\
\hline Leucine & 0.742 & 0.766 & 0.753 & 0.738 & 0.123 & 0.871 & 0.760 & 0.472 \\
\hline Lysine & 0.796 & 0.791 & 0.767 & 0.758 & 0.095 & 0.715 & 0.118 & 0.917 \\
\hline Methionine & 0.811 & 0.812 & 0.793 & 0.785 & 0.141 & 0.905 & 0.472 & 0.886 \\
\hline Phenylalanine & 0.742 & 0.781 & 0.768 & 0.744 & 0.130 & 0.791 & 0.832 & 0.258 \\
\hline Threonine & 0.746 & 0.745 & 0.763 & 0.746 & 0.082 & 0.617 & 0.630 & 0.662 \\
\hline Valine & 0.721 & 0.740 & 0.737 & 0.727 & 0.150 & 0.894 & 0.965 & 0.660 \\
\hline Means & 0.750 & 0.772 & 0.764 & 0.749 & - & - & - & - \\
\hline $\mathrm{SD}^{\mathrm{c}}$ & 4.41 & 2.87 & 2.89 & 2.48 & - & - & - & - \\
\hline \multicolumn{9}{|l|}{ Dispensable AA } \\
\hline Alanine & 0.780 & 0.792 & 0.801 & 0.804 & 0.060 & 0.544 & 0.178 & 0.694 \\
\hline Aspartic acid & 0.698 & 0.712 & 0.689 & 0.719 & 0.079 & 0.198 & 0.959 & 0.613 \\
\hline Cysteine & 0.671 & 0.681 & 0.676 & 0.692 & 0.091 & 0.455 & 0.222 & 0.614 \\
\hline Glutamic acid & 0.750 & 0.773 & 0.780 & 0.772 & 0.161 & 0.834 & 0.679 & 0.673 \\
\hline Glycine & 0.701 & 0.704 & 0.692 & 0.707 & 0.083 & 0.355 & 0.231 & 0.415 \\
\hline Proline & 0.807 & 0.820 & 0.811 & 0.803 & 0.111 & 0.908 & 0.786 & 0.655 \\
\hline Serine & 0.815 & 0.840 & 0.829 & 0.827 & 0.061 & 0.366 & 0.970 & 0.305 \\
\hline Tyrosine & 0.740 & 0.775 & 0.728 & 0.746 & 0.153 & 0.420 & 0.525 & 0.795 \\
\hline Means & 0.745 & 0.762 & 0.751 & 0.759 & - & - & - & - \\
\hline $\mathrm{SD}^{\mathrm{c}}$ & 5.28 & 5.74 & 6.15 & 5.03 & - & - & - & - \\
\hline
\end{tabular}

${ }^{\text {a }}$ MC: multicarbohydrase; Phy: Phytase. SEM: Standard error of mean.

${ }^{b}$ Effect of MC, Phy and interaction MC*Phy, respectively.

c Standard deviation.

digestibility coefficients. Coca-Sinova et al. (2010) compared isonutritive diets based on soybean meal with $46.3 \%$ or $48.6 \%$ crude protein and observed that dry matter digestibility was greater for the high-protein soybean meal. In the present study, the ATTD of CP in MFFS was 4.5\% lower than that found in Rostagno et al. (2011), whereas the average AID and SID of AA were 10 and 6\% lower, respectively, than those for FFS reported in NRC (2012). The digestible (DE) and metabolizable (ME) energy values for MFFS without enzyme supplementation were respectively 6.7 and 4.7\% lower than those for MFFS reported by Rostagno et al. (2011) for similar ingredients and 1.9 and $4.6 \%$ higher than the FFS values described in NRC (2012).

The lower digestibility values for most nutrients and energy in non-enzyme supplemented MFFS, compared to those reported in the literature, also suggest lower digestibility in weaned piglets compared to older pigs whose digestive capacity is further developed. Thus, the literature data could overestimate digestibility coefficients for some nutrients when extrapolating data from physiologically more mature pigs since after weaning, physiological functions of the small intestine gradually increase when the piglets start to eat solid feed (Marion et al., 2003; Boudry et al., 2004). These considerations agree with published research (Berrocoso et al., 2013), where micronization of soybean meal improved average daily feed intake and the gain:feed ratio of pigs during the first days postweaning but not thereafter. The physiological development of the gastrointestinal tract during growing phases has implications for ingredient digestion and nutrient utilization (Trindade Neto et al., 2010). Thus, the differences among experiments are not known

Table 6

Coefficient of apparent total tract digestibility in textured soy flour (TS) with or without enzymes for weaned piglets. ${ }^{\text {a }}$

\begin{tabular}{|c|c|c|c|c|c|c|c|c|}
\hline \multirow[t]{2}{*}{ Item, \% } & \multicolumn{4}{|c|}{ Treatment } & \multirow[t]{2}{*}{ SEM } & \multicolumn{3}{|c|}{$P$-value $e^{\mathrm{b}}$} \\
\hline & TS & $\begin{array}{l}\text { TS + } \\
\text { MC }\end{array}$ & $\begin{array}{l}\text { TS + } \\
\text { Phy }\end{array}$ & $\begin{array}{l}\text { TS + } \\
\text { MC + Phy }\end{array}$ & & MC & Phy & MC*Phy \\
\hline DM & 0.870 & 0.896 & 0.884 & 0.879 & 0.048 & 0.289 & 0.829 & 0.118 \\
\hline $\mathrm{CP}$ & 0.881 & 0.892 & 0.904 & 0.921 & 0.043 & 0.032 & $<0.001$ & 0.596 \\
\hline $\mathrm{DE}(\mathrm{mJ} / \mathrm{kg})^{\mathrm{c}}$ & 16.17 & 16.20 & 16.04 & 15.75 & 0.007 & 0.341 & 0.051 & 0.251 \\
\hline $\mathrm{ME}(\mathrm{mJ} / \mathrm{kg})^{\mathrm{c}}$ & 15.06 & 15.28 & 15.07 & 14.79 & 0.007 & 0.808 & 0.075 & 0.071 \\
\hline $\mathrm{ME} / \mathrm{GE}$ & 0.803 & 0.814 & 0.803 & 0.781 & 0.059 & 0.631 & 0.158 & 0.152 \\
\hline
\end{tabular}

SEM: Standard error of mean.

a MC: multicarbohydrase; Phy: phytase. DM: Dry matter; CP: Crude protein; DE: Digestible energy; ME: Metabolizable energy; ME/GE: Metabolizable energy/Gross energy.

${ }^{\mathrm{b}}$ Effect of MC, Phy and interaction MC*Phy, respectively.

c DM-basis. 
Table 7

Coefficient of apparent ileal digestibility of amino acids in textured soy flour (TS) with or without enzymes for weaned piglets. ${ }^{\text {a }}$

\begin{tabular}{|c|c|c|c|c|c|c|c|c|}
\hline \multirow[t]{2}{*}{ Item, \% } & \multicolumn{4}{|c|}{ Treatment } & \multirow[t]{2}{*}{ SEM } & \multicolumn{3}{|c|}{$P$-value ${ }^{\mathrm{b}}$} \\
\hline & TS & $\begin{array}{l}\mathrm{TS}+ \\
\mathrm{MC}\end{array}$ & $\begin{array}{l}\text { TS + } \\
\text { Phy }\end{array}$ & $\begin{array}{l}\text { TS + } \\
\text { MC + Phy }\end{array}$ & & MC & Phy & MC*Phy \\
\hline \multicolumn{9}{|c|}{ Indispensable AA } \\
\hline Arginine & 0.919 & 0.925 & 0.914 & 0.913 & 0.018 & 0.547 & 0.013 & 0.277 \\
\hline Histidine & 0.890 & 0.910 & 0.882 & 0.893 & 0.031 & 0.003 & 0.015 & 0.412 \\
\hline Isoleucine & 0.895 & 0.911 & 0.895 & 0.897 & 0.031 & 0.161 & 0.254 & 0.226 \\
\hline Leucine & 0.891 & 0.909 & 0.891 & 0.891 & 0.030 & 0.084 & 0.096 & 0.079 \\
\hline Lysine & 0.914 & 0.926 & 0.915 & 0.909 & 0.024 & 0.532 & 0.087 & 0.069 \\
\hline Methionine & 0.910 & 0.922 & 0.900 & 0.903 & 0.035 & 0.240 & 0.039 & 0.441 \\
\hline Phenylalanine & 0.902 & 0.912 & 0.905 & 0.899 & 0.023 & 0.648 & 0.338 & 0.086 \\
\hline Threonine & 0.817 & 0.844 & 0.813 & 0.810 & 0.053 & 0.210 & 0.063 & 0.120 \\
\hline Valine & 0.879 & 0.895 & 0.879 & 0.875 & 0.033 & 0.347 & 0.135 & 0.127 \\
\hline Means & 0.891 & 0.906 & 0.888 & 0.888 & - & - & - & - \\
\hline $\mathrm{SD}^{\mathrm{c}}$ & 3.05 & 2.50 & 3.09 & 3.10 & - & - & - & - \\
\hline \multicolumn{9}{|l|}{ Dispensable AA } \\
\hline Alanine & 0.838 & 0.865 & 0.860 & 0.842 & 0.050 & 0.662 & 0.930 & 0.094 \\
\hline Aspartic acid & 0.862 & 0.887 & 0.866 & 0.862 & 0.037 & 0.097 & 0.117 & 0.075 \\
\hline Cystine & 0.707 & 0.772 & 0.721 & 0.756 & 0.105 & 0.015 & 0.935 & 0.430 \\
\hline Glutamic acid & 0.895 & 0.913 & 0.884 & 0.892 & 0.030 & 0.004 & $<0.001$ & 0.189 \\
\hline Glycine & 0.762 & 0.811 & 0.756 & 0.775 & 0.073 & 0.012 & 0.094 & 0.222 \\
\hline Proline & 0.872 & 0.893 & 0.868 & 0.866 & 0.039 & 0.161 & 0.033 & 0.093 \\
\hline Serine & 0.829 & 0.868 & 0.849 & 0.838 & 0.050 & 0.107 & 0.545 & 0.008 \\
\hline Tyrosine & 0.885 & 0.913 & 0.892 & 0.894 & 0.035 & 0.016 & 0.288 & 0.025 \\
\hline Means & 0.831 & 0.865 & 0.837 & 0.840 & - & - & - & - \\
\hline $\mathrm{SD}^{\mathrm{c}}$ & 6.51 & 4.99 & 6.31 & 5.08 & - & - & - & - \\
\hline
\end{tabular}

${ }^{a}$ Phy: Phytase. SEM: Standard error of mean.

b Effect of MC, Phy and interaction MC*Phy, respectively.

c Standard deviation.

Table 8

Coefficient of standardized ileal digestibility of amino acids in textured soy flour (TS) with or without enzymes for weaned piglets. ${ }^{\text {a }}$

\begin{tabular}{|c|c|c|c|c|c|c|c|c|}
\hline \multirow[t]{2}{*}{ Item, \% } & \multicolumn{4}{|c|}{ Treatment } & \multirow[t]{2}{*}{ SEM } & \multicolumn{3}{|c|}{$P$-value ${ }^{\mathrm{b}}$} \\
\hline & TS & $\begin{array}{l}\mathrm{TS}+ \\
\mathrm{MC}\end{array}$ & $\begin{array}{l}\text { TS + } \\
\text { Phy }\end{array}$ & $\begin{array}{l}\text { TS + } \\
\text { MC + Phy }\end{array}$ & & MC & Phy & MC*Phy \\
\hline \multicolumn{9}{|c|}{ Indispensable AA } \\
\hline Arginine & 0.931 & 0.936 & 0.926 & 0.925 & 0.002 & 0.589 & 0.013 & 0.288 \\
\hline Histidine & 0.945 & 0.965 & 0.938 & 0.949 & 0.003 & 0.003 & 0.022 & 0.377 \\
\hline Isoleucine & 0.944 & 0.959 & 0.945 & 0.945 & 0.031 & 0.203 & 0.288 & 0.227 \\
\hline Leucine & 0.940 & 0.958 & 0.942 & 0.941 & 0.030 & 0.109 & 0.124 & 0.078 \\
\hline Lysine & 0.943 & 0.955 & 0.943 & 0.938 & 0.024 & 0.431 & 0.063 & 0.065 \\
\hline Methionine & 0.927 & 0.937 & 0.918 & 0.921 & 0.035 & 0.348 & 0.071 & 0.548 \\
\hline Phenylalanine & 0.945 & 0.957 & 0.948 & 0.943 & 0.023 & 0.425 & 0.189 & 0.079 \\
\hline Threonine & 0.909 & 0.939 & 0.919 & 0.916 & 0.053 & 0.194 & 0.489 & 0.097 \\
\hline Valine & 0.936 & 0.952 & 0.937 & 0.933 & 0.033 & 0.333 & 0.153 & 0.109 \\
\hline Means & 0.936 & 0.951 & 0.935 & 0.934 & - & - & - & - \\
\hline $\mathrm{SD}^{\mathrm{c}}$ & 1.18 & 1.08 & 1.11 & 1.18 & - & - & - & - \\
\hline \multicolumn{9}{|l|}{ Dispensable AA } \\
\hline Alanine & 0.928 & 0.954 & 0.951 & 0.932 & 0.050 & 0.713 & 0.988 & 0.127 \\
\hline Aspartic acid & 0.884 & 0.909 & 0.888 & 0.885 & 0.037 & 0.094 & 0.130 & 0.070 \\
\hline Cystine & 0.844 & 0.902 & 0.854 & 0.905 & 0.105 & 0.009 & 0.740 & 0.864 \\
\hline Glutamic acid & 0.946 & 0.964 & 0.936 & 0.944 & 0.030 & 0.004 & $<0.001$ & 0.195 \\
\hline Glycine & 0.844 & 0.894 & 0.839 & 0.858 & 0.073 & 0.012 & 0.104 & 0.213 \\
\hline Proline & 0.935 & 0.946 & 0.932 & 0.929 & 0.039 & 0.182 & 0.041 & 0.093 \\
\hline Serine & 0.919 & 0.956 & 0.939 & 0.929 & 0.050 & 0.121 & 0.708 & 0.011 \\
\hline Tyrosine & 0.918 & 0.946 & 0.926 & 0.927 & 0.035 & 0.017 & 0.337 & 0.024 \\
\hline Means & 0.902 & 0.934 & 0.908 & 0.914 & - & - & - & - \\
\hline $\mathrm{SD}^{\mathrm{c}}$ & 4.01 & 2.77 & 4.24 & 2.91 & - & - & - & - \\
\hline
\end{tabular}

${ }^{\text {a }}$ MC: multicarbohydrase; Phy: Phytase. SEM: Standard error of mean.

${ }^{\mathrm{b}}$ Effect of MC, Phy and interaction MC*Phy, respectively.

c Standard deviation. 
but might be related to factors such as the size and uniformity of the feed particles, the feed form (pellet vs. mash), and the age and health status of the piglets (Nir et al., 1994; Berrocoso et al., 2013; Fiorentini et al., 2014). For example, a reduction in feed particle size might improve nutrient digestibility because of better mixing of dietary components and enzymes but also might affect the motility of the gastrointestinal tract and the general health status of the pig (Mikkelsen et al., 2004; Hedemann et al., 2005, 2006). Both effects counteract each other, and the magnitude of the observed response will vary among experiments. Fastinger and Mahan (2003) observed an increase in AA digestibility due to particle size reduction of soybean meal, whereas Lawrence et al. (2003) did not find such differences. In the present evaluation, the AA digestibility values were $4.5 \%$ lower than those described in the literature, which could be due to physiological limitations, such as incompletely developed enzymatic digestion during the post-weaning phase (Gu and Li, 2003). There was a small numeric increase in the SID of indispensable AA in MFFS with MC supplementation: 1.1 and $2.9 \%$ points compared with Phy or Phy + MC inclusion, respectively, and 1.4\% points in the ATTD of CP when the enzymes were used in combination compared with isolated inclusion. The low content of antinutritional factors in MFFS (ureatic activity and KOH solubility) in the present study may have limited the enzyme activity considering that most of the studies on exogenous enzymes have shown controversial results due to differences in the type and quantity of cereal grains used, the age of the animals, the extent of deficiency of limiting nutrients, and the extent to which the enzyme increased digestible nutrient content (Adeola and Cowieson, 2011). Phytate and non-starch polysaccharides are some of the main antinutritional components in plant-based feedstuffs, and the ability of exogenous enzymes to improve nutrient digestibility will vary depending on the quantity of those components present in the feed ingredients (Olukosi et al., 2007; Emiola et al., 2009).

\subsection{Experiment 2: textured soy flour}

Very little information about nutritive values of textured soy products for growing pigs is available in the literature. Hill et al. (2000, 2001) studied the textured vegetable protein from soy in canine canned diets and concluded that the AA digestibility was similar to that of beef. The nutrient digestibility values of various soybean products processed under different conditions (full fat extruded soybean, semi-full fat extruded soybean and soybean protein concentrate) presented in the food composition and nutritional requirements publication (Rostagno et al., 2011) were generally lower than those of TS obtained in the present study.

In the current study, ATTD of CP increased by 1.1 and $2.3 \%$ points with Phy and MC supplementation, respectively. The primary reason for supplementing swine diets with Phy is to facilitate the breakdown of phytate molecules to release phosphorus. Phytic acid is naturally associated with proteins in aleurone layers of cereal grains and with protein in oilseeds, and it binds proteins and divalent cations such as $\mathrm{Ca}^{2+}, \mathrm{Mg}^{2+}$, and $\mathrm{Zn}^{2+}$ to form protein-mineral-phytate complexes thus reducing the efficiency of nutrient utilization (DeBoland et al., 1975; Grynspan and Cheryan, 1983). Therefore, not only phytate P release but also amino acid digestibility and energy efficiency may be used as additional parameters to determine the effectiveness of phytase (Dersjant-Li et al., 2015). Carbohydrase supplementation has been proposed as a means of improving the energy and nutrient digestibility in various feedstuffs fed to pigs (Omogbenigun et al., 2004; Emiola et al., 2009). This supports previous reports by Omogbenigun et al. (2004), in which it was observed that multi-enzyme supplementation improved the ileal digestibility of DM, CP, and GE in young pigs fed a corn-soybean meal diet. As suggested by Emiola et al. (2009), the ability of exogenous enzymes to improve nutrient digestibility depends on enzyme activity and substrate availability.

In the current study, the SID of most AA was higher than $90 \%$ even when the exogenous enzymes were not provided. Compared with MFFS, the mean SID of AA in TS was approximately 17.2 percentage points higher. Although many external factors may be involved in these results, the soybean extrusion process seems to provide a high-quality product for pig diets. Moist extrusion already has been proposed as a way to improve digestibility and pig performance (Li et al., 1991; Friesen et al., 1993). When Friesen et al. (1993) compared dry versus moist extrusion processing to enhance soybean meal quality, they reported that the second process was better for inclusion in starter pig diets, ensuring an increase in average daily gain and feed conversion. Compared to dry processing, moist extrusion may result in superior product due to greater control in preventing overheating, which can cause lower product digestibility. Li et al. (1991) suggested that extruded soy protein concentrate produces a lower transient hypersensitivity response in piglets. Due to lack of information about TS in the literature (NRC, 2012; Rostagno et al., 2011), we could not compare the digestibility results.

There was a small numeric increase in the SID of indispensable AA in TS with MC supplementation: 1.7 percentage points compared with Phy or Phy + MC inclusion. Similar to micronized full fat soybean, low levels of non-starch polysaccharides and phytate as substrates for enzymes in TS may have limited the enzymes' activity (Vicente et al., 2008) based on ureatic activity and protein solubility and the absence of MC and Phy effects on digestibility of most analysed AA. Interactions between the enzymes were found in the digestibility of the non-essential AA Ser and Tyr. The interactions might be caused by changes in digesta passage rate, $\mathrm{pH}$ and contact time of the enzyme with its substrate (Nortey et al., 2007). There were no interactions $(P>0.05)$ between MC and Phy on the AID or SID of essential AA in TS.

\section{Conclusion}

Our results on digestibility indicate differences compared with those reported in the literature. Due to a lack of information regarding TS, mainly in requirement tables for growing pigs, it was difficult to compare the present data with other researchers' results; however, most digestibility values for MFFS evidenced a numerical difference compared with previous studies from the literature. Since most studies have used ileal-cannulated pigs older than six weeks, we suggest that weaned pigs are less able to harness the energy and nutrients from ingredients when compared to growing-finishing pigs. However, since digestibility of raw 
materials differs from batch to batch and from experiment to experiment, more researches should be conducted to compare the digestibility of ingredients for piglets in different ages. The enzymes phytase and multicarbohydrase may be an alternative way to increase the digestibility of crude protein in both ingredients.

\section{Acknowledgements}

\section{The authors gratefully acknowledge The Sao Paulo Research Foundation (FAPESP) for financial support on Project 2012/00517-0 and Coordination for the Improvement of Higher Education Personnel (CAPES) for a scholarship.}

\section{References}

AOAC, 2005. Official Methods of Analysis, 18th ed. Assoc. Off. Anal. Chem., Arlington, VA.

AOCS, 1980. The American Oil Chemists' Society. Urease activity. Official Method Ba, Champaign, IL, USA, pp. 9-58.

Adeola, O., Cowieson, A.J., 2011. Board-invited review: opportunities and challenges in using exogenous enzymes to improve nonruminant animal production. J. Anim. Sci. 89, 3189-3218.

Adeola, O., Sands, J.S., 2003. Does supplemental dietary microbial phytase improve amino acid utilization? A perspective that it does not. J. Anim. Sci. 81, 78-85. Berrocoso, J.D., Serrano, M.P., Cámara, L., López, A., Mateos, G.G., 2013. Influence of source and micronization of soybean meal on nutrient digestibility and growth performance of weanling pigs. J. Anim. Sci. 91, 309-317.

Boudry, G., Peron, V., Le Huerou-Luron, I., Lallès, J.P., Sève, B., 2004. Weaning induces both transient and long-lasting modifications of absorptive, secretory, and barrier properties of piglet intestine. J. Nutr. 134, 2256-2262.

Butolo, J.E., 2002. Qualidade de ingredientes na alimentação animal. CBNA, Campinas, Brazil.

Centeno, C., Arija, I., Viveros, A., Brenes, A., 2007. Effects of citric acid and microbial phytase on amino acid digestibility in broiler chickens. Br. Poult. Sci. 48, 469-479.

Clarke, E.J., Wiseman, J., 2000. Developments in plant breeding for improved nutritional quality of soya beans II: anti-nutrition al factors. J. Agric. Sci. 134, 125-136.

Coca-Sinova, A., Jiménez-Moreno, E., González-Alvarado, J.M., Frikha, M., Lázaro, R., Mateos, G.G., 2010. Influence of source of soybean meal and lysine content of the diet on performance and total tract apparent retention of nutrients in broilers from 1 to 36 days of age. Poult. Sci. 89, $1440-1450$.

Cowieson, A.J., Bedford, M.R., 2009. The effect of phytase and carbohydrase on ileal amino acid digestibility in monogastric diets: complimentary mode of action? World's Poult. Sci. J. 65, 609-624.

DeBoland, A.R., Garner, G.B., O’Dell, B.L., 1975. Identification and properties of phytate in cereal grains and oilseed products. J. Agric. Food Chem. 23, 1186-1192.

Dersjant-Li, Y., Schulze, A.H., Partridge, G., 2015. Phytase in non-ruminant animal nutrition: a critical review on phytase activities in the gastrointestinal tract and influencing factors. J. Sci. Food Agric. 30 (95), 878-896.

Donkoh, A., Moughan, P.J., Smith, W.C., 1994. Comparison of the slaughter method and simple T-piece cannulation of the terminal ileum for determining ileal amino acid digestibility in meat and bone meal for the growing pig. Anim. Feed Sci. Technol. 49, 43-56.

Emiola, I.A., Opapeju, F.O., Slominski, B.A., Nyachoti, C.M., 2009. Growth performance and nutrient digestibility in pigs fed wheat distillers dried grains with solublesbased diets supplemented with a multicarbohydrase enzyme. J. Anim. Sci. 87, 2315-2322.

Fastinger, N.D., Mahan, D.C., 2003. Effect of soybean meal particle size on amino acid and energy digestibility in grower-finisher swine. J. Anim. Sci. 81, 697-704.

Fiorentini, G., Carvalho, I.P.C., Messana, J.D., Castagnino, P.S., Berndt, A., Canesin, R.C., Frighetto, R.T.S., Berchielli, T.T., 2014. Effect of lipid sources with different fatty acid profiles on the intake, performance, and methane emissions of feedlot Nellore steers. J. Anim. Sci. 92, 1613-1620.

Friesen, K.G., Nelssen, J.L., Goodband, R.D., Behnke, K.C., Kats, L.J., 1993. The effect of moist extrusion of soy products on growth performance and nutrient utilization in the early-weaned pig. J. Anim. Sci. 71, 2099-2109.

Goering, H.K., Van Soest, P.J., 1970. Forage Fiber Analysis (Apparatus, Reagents, Procedures and Some Applications). Agricultural Handbook. US Dept. Agric. Agric. Res. Serv., Washington, D.C. USA.

Grynspan, F., Cheryan, M., 1983. Calcium phytate: effect of pH and molar ratio on in vitro solubility. J. Am. Oil Chem. Soc. 60, $1761-1764$.

Gu, X., Li, D., 2003. Fat nutrition and metabolism in piglets: a review. Anim. Feed Sci.Technol. 109, 151-170.

Hedemann, M.S., Mikkelsen, L.L., Naughton, P.J., Jensen, B.B., 2005. Effect of feed particle size and feed processing on morphological characteristics in the small and large intestine of pigs and on adhesion of Salmonella enterica serovar Typhimurium DT12 in the ileum in vitro. J. Anim. Sci. 83, $1554-1562$.

Hedemann, M.S., Eskildsen, M., Laerke, H.N., Pedersen, C., Lindberg, J.E., Laurinen, P., Knudsen, K.E., 2006. Intestinal morphology and enzymatic activity in newly weaned pigs fed contrasting fiber concentrations and fiber properties. J. Anim. Sci. 84, 1375-1386.

Hill, R.C., Burrows, C.F., Ellison, G.W., Bauer, J.E., 2000. The effect of texturized vegetable protein containing soy carbohydrate on oroileal transit of chromic oxide in cannulated dogs. J. Anim. Sci. 78, 2633-2638.

Hill, R.C., Burrows, C.F., Ellison, G.W., Bauer, J.E., 2001. The effect of texturized vegetable protein from soy on nutrient digestibility compared to beef in cannulated dogs. J. Anim. Sci. 79, 2162-2171.

Igbasan, F.A., Guenter, W., 1997. The influence of micronization, dehulling, and enzyme supplementation on the nutritive value of peas for laying hens. Poult. Sci. 76, 331-337.

Kim, S.W., Zhang, J.H., Soltwedel, K.T., Knabe, D.A., 2006. Use of carbohydrases in corn-soybean meal based grower-finisher pig diets. Anim. Res. 55, 563-578.

Kong, C., Adeola, O., 2011. Protein utilization and amino acid digestibility of canola meal in response to phytase in broiler chickens. Poult. Sci. 90, $1508-1515$.

Lawrence, K.R., Hastad, C.W., Goodband, R.D., Tokach, M.D., Dritz, S.S., Nelssen, J.L., Derouchey, J.M., Webster, M.J., 2003. Effects of soybean meal particle size on growth performance of nursery pigs. J. Anim. Sci. 81, 2118-2122.

Lawrence, T.L.J., 1973. An evaluation of the micronization process for preparing cereals for the growing pig. 1. Effects on digestibility and nitrogen retention. Anim. Prod. 16, 99-107.

Li, D.F., Nelssen, J.L., Reddy, P.G., Blecha, F., Klemm, R.D., Giesting, D.W., Hancock, J.D., Allee, G.L., Goodband, R.D., 1991. Measuring suitability of soybean products for early weaned pigs with immunological criteria. J. Anim. Sci. 69, 3299-3307.

Li, S., Sauer, W.C., Fan, M.Z., 1993. The effect of dietary crude protein level on ileal and fecal amino acid digestibility in early-weaned pigs. J. Anim. Physiol. Anim. Nutr. 70, 117-128.

Li, Y., Chen, X., Chen, Y., Li, Z., Cao, Y., 2010. Effects of $\beta$-mannanase expressed by Pichia pastoris in corn-soybean meal diets on broiler performance, nutrient digestibility, energy utilization and immunoglobulin levels. Anim. Feed Sci. Technol. 159, 59-67.

Marion, J., Romé, V., Savary, G., Thomas, F., Le Dividich, J., Le Huerou-Luron, I., 2003. Weaning and feed intake alter pancreatic enzyme activities and corresponding mRNA levels in 7-d-old piglets. J. Nutr. 133, 362-368.

Mikkelsen, L.L., Naughton, P.J., Hedemann, M.S., Jensen, B.B., 2004. Effects of physical properties of feed on microbial ecology and survival of Salmonella enterica serovar Typhimurium in the pig gastrointestinal tract. Appl. Environ. Microbiol. 70, 3485-3492.

NRC, 2012. Nutrient Requirements of Swine, 11th rev. ed. Natl. Acad. Press, Washington, DC.

Nir, I., Hillel, R., Shefet, G., Nitsan, Z., 1994. Effect of grain particle size on performance. 2. Grain texture interaction. Poult. Sci. 73, 781-791.

Nortey, T.N., Patience, J.F., Simmins, P.H., Trottier, N.L., Zijlstra, R.T., 2007. Effects of individual or combined xylanase and phytase supplementation on energy, amino acid, and phosphorus digestibility and growth performance of grower pigs fed wheat-based diets containing wheat millrun. J. Anim. Sci. 85, 1432-1443.

Nyachoti, C.M., De Lange, C.F.M., Schulze, H., 1997. Estimating endogenous amino acid flows at the terminal ileum and true ileal amino acid digestibilities in diets for growing pigs using the homoarginine method. J. Anim. Sci. 75, 3206-3213. 
Nyachoti, C.M., Arntfield, S.D., Guenter, W., Cenkowski, S., Opapeju, F.O., 2006. Effect of micronized pea and enzyme supplementation on nutrient utilization and manure output in growing pigs. J. Anim. Sci. 84, 2150-2156.

Olukosi, O.A., Cowieson, A.J., Adeola, O., 2007. Age-related influence of a cocktail of xylanase, amylase, and protease or phytase individually or in combination in broilers. Poult. Sci. 86, 77-86.

Omogbenigun, F.O., Nyachoti, C.M., Slominski, B.A., 2004. Dietary supplementation with multienzyme preparations improves nutrient utilization and growth performance in weaned pigs. J. Anim. Sci. 82, 1053-1061.

Opapeju, F.O., Golian, A., Nyachoti, C.M., Campbell, L.D., 2006. Amino acid digestibility in dry extruded-expelled soybean meal fed to pigs and poultry. J. Anim. Sci. 84, 1130-1137.

Radcliffe, J.S., Pleasant, R.S., Kornegay, E.T., 2006. Estimating equivalency values of microbial phytase for amino acids in growing and finishing pigs fitted with steered ileo-cecal valve cannulas. J. Anim. Sci. 84, 1119-1129.

Rodrigues, E.A., Badiola, I., Francesch, M., Torrallardona, D., 2016. Effect of cereal extrusion on performance, nutrient digestibility, and cecal fermentation in weanling pigs. J. Anim. Sci. 94, 298-302.

Rojas, O.J., Vinyeta, E., Stein, H.H., 2016. Effects of pelleting extrusion, or extrusion and pelleting on energy and nutrient digestibility in diets containing different levels of fiber and fed to growing pigs. J. Anim. Sci. 94, 1951-1960.

Rostagno, H.S., Albino, L.F.T., Donzele, J.L., Gomes, P.C., Oliveira, R.F., 2011. Tabelas Brasileiras para aves e suínos. Composição de Alimentos e Exigências Nutricionais (Brazilian Tables for broilers and pigs. Food composition and Nutritional requirements). 3rd ed. Viçosa, MG, Brazil.

Sands, J.S., Ragland, D., Dilger, R.N., Adeola, O., 2009. Responses of pigs to Aspergillus niger phytase supplementation of low-protein or high-phytin diets. J. Anim. Sci. 87, 2581-2589.

Traylor, S.L., Cromwell, G.L., Lindemann, M.D., Knabe, D.A., 2001. Effects of level of supplemental phytase on ileal digestibility of amino acids, calcium and phosphorus in dehulled soybean meal for growing pigs. J. Anim. Sci. 79, 2634-2642.

Trindade Neto, M.A., Berto, D.A., Nyachoti, C.M., Schammass, E.A., 2010. Energy and amino acid content in phase 1 nursery diet: piglet performance and body chemical composition. Braz. J. Anim. Sci. 39, 1286-1294.

Vicente, B., Valencia, D.G., Perez-Serrano, M., Lazaro, R., Mateos, G.G., 2008. The effects of feeding rice in substitution of corn and the degree of starch gelatinization of rice on the digestibility of dietary components and productive performance of young pigs. J. Anim. Sci. 86, 119-126.

Williams, C.H., David, D.J., Lismaa, O., 1962. The determination of chromic oxide in feces samples by atomic absorption spectrophotometry. J. Agric. Sci. 59, 381-385.

Woyengo, T.A., Nyachoti, C.M., 2011. Supplementation of phytase and carbohydrases to diets for poultry: a review. Can. J. Anim. Sci. 91, $177-192$.

Woyengo, T.A., Nyachoti, C.M., 2013. Anti-nutritional effects of phytic acid in diets for pigs and poultry-current knowledge and directions for future research: a review. Can. J. Anim. Sci. 93, 9-21.

Woyengo, T.A., Kiarie, E., Nyachoti, C.M., 2010. Energy and amino acid utilization in expeller-extracted canola meal fed to growing pigs. J. Anim. Sci. 88, 1433-1441.

Woyengo, T.A., Beltranena, E., Zijlstra, R.T., 2014. Nonruminant Nutrition Symposium: controlling feed cost by including alternative ingredients into pig diets: a review. J. Anim. Sci. 92, 1293-1305.

Woyengo, T.A., Patterson, R., Levesque, C.L., 2016. Nutritive value of extruded or multi-enzyme supplemented cold-pressed soybean cake for pigs. J. Anim. Sci. 94 $5230-5238$.

Zhang, M., Nyachoti, C.M., Arntfield, S.D., Guenter, W., Cenkowski, S., 2003. Effect of micronization of peas and enzyme supplementation on nutrient excretion and manure volume in growing pigs. Can. J. Anim. Sci. 83, 749-754.

Zijlstra, R.T., Owusu-Asiedu, A., Simmins, A.H., 2010. Future of NSP-degrading enzymes to improve nutrient utilization of coproducts and gut health in pigs. Livest. Sci. 134, 255-257. 